\title{
Cranially-based nasolabial flaps for the reconstruction of nasal surgical defects
}

\author{
Hakan Kerem ${ }^{1}$, Ulaş Bali ${ }^{1}$, Erhan Sönmez ${ }^{2}$, Mustafa Kürşat Evrenos ${ }^{1}$ \\ ${ }^{1}$ Department of Plastic and Reconstructive Surgery, Celal Bayar University Faculty of Medicine, Manisa; ${ }^{2}$ Department of Plastic and \\ Reconstructive Surgery, Katip Celebi University Ataturk Training and Research Hospital, Izmir, Turkey
}

Background Cranially-based nasolabial flaps are a good alternative for the reconstruction of nasal defects.

Methods A cranially-based nasolabial flap was used in 18 patients to reconstruct defects of the nose from 2010 to 2016, and the long-term results are presented in this report.

Results Fifteen of the flaps completely survived. All the patients had a bulky appearance, but they did not want to undergo a second operation for cosmesis. The dissection of the flap took approximately 20 minutes, and the total operation lasted for 1 hour. The patients were hospitalized for 1-7 days, and the postoperative follow-up period was 1-28 months (mean, 17 months).

Conclusions The cranially-based nasolabial flap possesses all the advantages of the traditional forehead flap, and can safely be used in selected cases.

Keywords Surgical flap / Nose neoplasm / Reconstructive surgical procedures
Correspondence: Ulaş Bali Department of Plastic and Reconstructive Surgery, Celal Bayar University Faculty of Medicine, Manisa 45140, Turkey Tel: $+90-5066806736$ Fax: +90-2362321693 E-mail: zulasbali@gmail.com

This article was presented at the 35 th National Turkish Society of Plastic Reconstructive and Aethetic Surgery Congress on October 28-31, 2013, in Istanbul, Turkey.

Received: 7 Apr $2017 \bullet$ Revised: 2 Oct 2017 - Accepted: 24 Oct 2017

pISSN: 2234-6163 • elSSN: 2234-6171 • https://doi.org/10.5999/aps.2017.00689・Arch Plast Surg 2018;45:140-145

\section{INTRODUCTION}

Nasal reconstruction may be required in patients with congenital deformities, surgical defects following tumor resection, immune diseases, or trauma, including vascular injuries. The nose is a cosmetically and functionally important part of the face, so it is crucial for nasal reconstruction procedures to be functionally and aesthetically successful. The development of a thoughtful reconstructive plan is vitally important after enough time has passed for the deformity to be evaluated. The goal is to restore the pre-existing form and function of the nose without distorting adjacent anatomic structures, but this remains a challenge for plastic surgeons [1]. Nasal defects may be reconstructed by various methods, including local and free flaps [2,3]. Because of the ideal quality of the color and texture of skin from the fore- head, the forehead has been acknowledged as the best donor site for resurfacing the nose [4]. Our aim in this study was to show that there is another ideal donor site for resurfacing the nose. In this study, we present the long-term results obtained from using cranially-based nasolabial flaps to cover soft tissue defects of the nose. We used cranially-based nasolabial flaps in 18 patients to reconstruct defects of the nose from 2010 to 2016, and the long-term results are presented in this report.

\section{METHODS}

We conducted this study in compliance with the principles of the Declaration of Helsinki. There were 11 male and 7 female patients in this series. The patients ranged in age from 63 to 84 years (mean, 71.2 years). The size of the defects ranged from 
$2.5 \times 2.5 \mathrm{~cm}$ to $4 \times 5 \mathrm{~cm}$. The follow-up period was $1-28$ months (mean, 17 months) (Table 1). All defects resulted from skin cancer treatment.

\section{Surgical technique}

The details of the technique of harvesting the cranially-based nasolabial flap have previously been described elsewhere $[5,6]$. Briefly, general anesthesia was used in all patients. The size of each flap was planned according to the size and the location of the tissue defect. The width of the flaps was designed to permit the primary closure of the donor site in the nasolabial fold, with variation according to patients' skin elasticity. By using a Mustarde flap, it was possible to harvest a wider flap. The harvesting of the flap started in the subcutaneous plane, moving from the caudal border towards the cranial direction. The branches of the angular vessels were coagulated with caution during the dissection of the flap. The plane of dissection changed from the subcutaneous to subperiosteal level at the rim of the nostril in order to preserve the angular artery, because the subcutaneous tissue at this level becomes very thin and the angular artery is at high risk. At the level of the nostril rim, the lateral nasal artery was coagulated. The dissection then continued in this plane cranially up to the level of the medial palpebral ligament (Fig. 1). Afterwards, the flap was adapted to the defect on the nose following careful hemostasis. In all cases, the angular artery remained continuous with the ophthalmic artery, and there were constant

Table 1. Demographic and clinicopathological characteristics of the study group

\begin{tabular}{|c|c|c|c|c|c|c|c|c|c|c|c|}
\hline $\begin{array}{l}\text { Patient } \\
\text { No. }\end{array}$ & $\begin{array}{l}\text { Age } \\
(y r)\end{array}$ & Sex & $\mathrm{SH}$ & DM & $\begin{array}{l}\text { Tumor size } \\
\text { (cm) }\end{array}$ & $\begin{array}{l}\text { Defect size } \\
\text { (cm) }\end{array}$ & Localization & Pathology & $\begin{array}{l}\text { Follow- } \\
\text { up } \\
\text { (mo) }\end{array}$ & Complications & $\begin{array}{l}\text { Location of } \\
\text { defect relative } \\
\text { to flap }\end{array}$ \\
\hline 1 & 84 & Male & - & + & $2 \times 2$ & $3 \times 3$ & Tip & Trichilemmal CA & 4 (death) & Bulky & Contralateral \\
\hline 2 & 68 & Male & + & - & $1.5 \times 1.5$ & $2.5 \times 2.5$ & Left wall & $\begin{array}{l}\text { Poorly differentiated } \\
\text { SCC }\end{array}$ & 4 & Bulky & Contralateral \\
\hline 3 & 75 & Female & - & - & $1.5 \times 1.5$ & $2.5 \times 2.5$ & $\begin{array}{l}\text { Left ala and left } \\
\text { wall }\end{array}$ & $\begin{array}{l}\text { Moderately } \\
\text { differentiated SCC }\end{array}$ & 3 & Bulky & Ipsilateral \\
\hline 4 & 82 & Female & - & + & $3 \times 3$ & $4 \times 4$ & $\begin{array}{l}\text { Right wall and } \\
\text { right ala }\end{array}$ & Superficial BCC & 19 & Venous congestion & Ipsilateral \\
\hline 5 & 74 & Male & - & + & $3.5 \times 3.5$ & $4.5 \times 4.5$ & Dorsum & Multifocal BCC & 28 & Bulky & $\begin{array}{l}\text { Contralateral and } \\
\text { ipsilateral }\end{array}$ \\
\hline 6 (Case 1) & 75 & Female & - & - & $2.5 \times 4$ & $3.5 \times 5$ & Dorsum & Multifocal BCC & 10 & Bulky & $\begin{array}{l}\text { Contralateral and } \\
\text { ipsilateral }\end{array}$ \\
\hline 7 & 73 & Male & + & + & $3 \times 3$ & $4 \times 4$ & Dorsum & Infiltrative BCC & 21 & Venous congestion & $\begin{array}{l}\text { Contralateral and } \\
\text { Ipsilateral }\end{array}$ \\
\hline 8 & 82 & Male & - & - & $3 \times 4$ & $4 \times 5$ & $\begin{array}{l}\text { Left ala and left } \\
\text { malar region }\end{array}$ & Basosquamous CA & 23 & Bulky & $\begin{array}{l}\text { Contralateral and } \\
\text { Ipsilateral }\end{array}$ \\
\hline 9 & 74 & Male & + & + & $1.5 \times 2$ & $2.5 \times 3$ & Left wall & Multifocal BCC & 25 & Bulky & Contralateral \\
\hline 10 (Case 2) & 79 & Female & - & - & $\begin{array}{l}1.5 \times 1.5 \\
\text { (dorsum) } \\
2 \times 2 \text { (tip) }\end{array}$ & $\begin{array}{l}3 \times 6 \\
(2 \text { lesions } \\
\text { excised together) }\end{array}$ & Dorsum and tip & Ulceronodular BCC & 21 & Bulky & $\begin{array}{l}\text { Contralateral and } \\
\text { Ipsilateral }\end{array}$ \\
\hline 11 & 73 & Female & - & - & $2 \times 2$ & $3 \times 3$ & $\begin{array}{l}\text { Right ala and } \\
\text { right wall }\end{array}$ & $\begin{array}{l}\text { Poorly differentiated } \\
\text { SCC }\end{array}$ & 14 & Bulky & Ipsilateral \\
\hline 12 & 80 & Male & - & - & $2 \times 2.5$ & $3 \times 3.5$ & Tip & Ulceronodular BCC & 17 & Bulky & $\begin{array}{l}\text { Contralateral and } \\
\text { ipsilateral }\end{array}$ \\
\hline 13 & 63 & Female & - & - & $2 \times 2$ & $3 \times 3$ & $\begin{array}{l}\text { Right ala and } \\
\text { right wall }\end{array}$ & Multifocal BCC & 26 & Bulky & Ipsilateral \\
\hline 14 & 65 & Male & + & - & $2 \times 2$ & $3 \times 3$ & Dorsum & Nodular BCC & 1 & Distal flap necrosis & $\begin{array}{l}\text { Contralateral and } \\
\text { ipsilateral }\end{array}$ \\
\hline 15 & 75 & Female & - & - & $3 \times 4$ & $4 \times 5$ & $\begin{array}{l}\text { Dorsum, tip, } \\
\text { and alae }\end{array}$ & Microinvasive SCC & 4 & Bulky & $\begin{array}{l}\text { Contralateral and } \\
\text { ipsilateral }\end{array}$ \\
\hline 16 & 67 & Male & - & - & $2 \times 3$ & $3 \times 4$ & Dorsum & Multifocal BCC & 9 & Bulky & $\begin{array}{l}\text { Contralateral and } \\
\text { ipsilateral }\end{array}$ \\
\hline 17 & 72 & Male & - & - & $2 \times 4$ & $3 \times 5$ & Left wall & Ulceronodular BCC & 12 & Bulky & Contralateral \\
\hline 18 & 71 & Male & - & - & $1 \times 3$ & $2 \times 4$ & Dorsum & Multifocal BCC & 16 & Bulky & $\begin{array}{l}\text { Contralateral and } \\
\text { ipsilateral }\end{array}$ \\
\hline
\end{tabular}




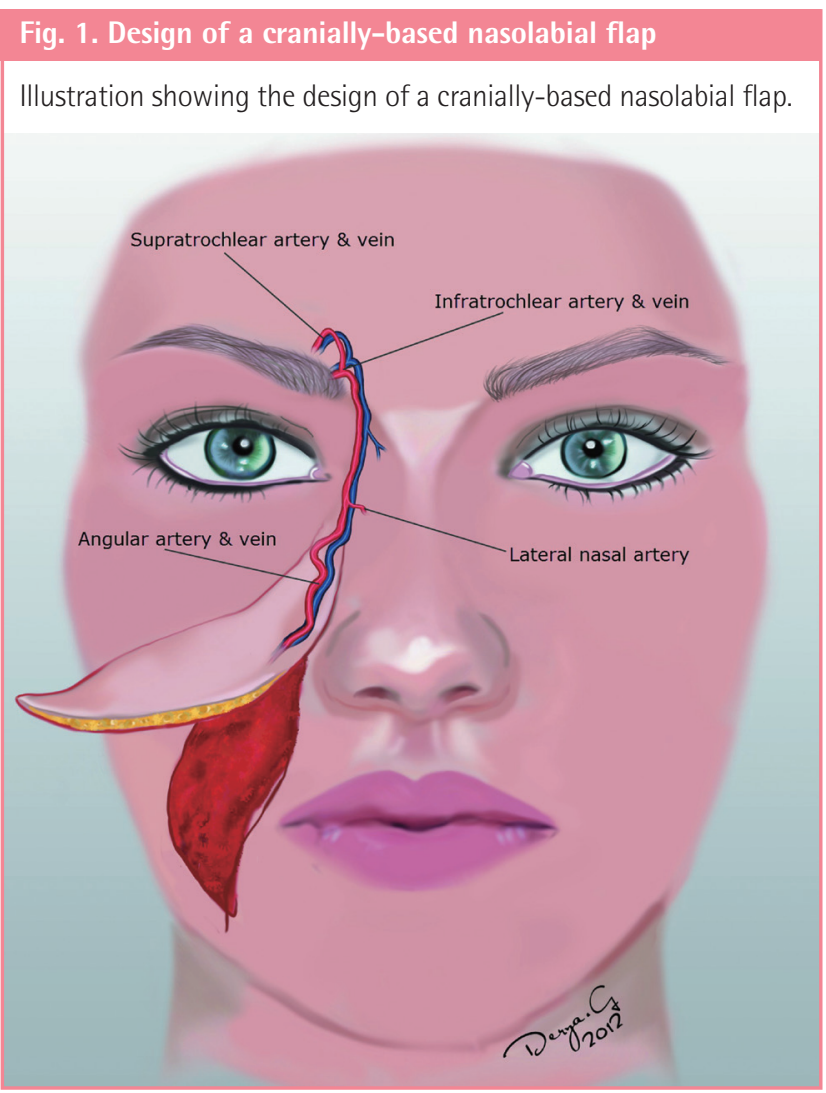

anastomoses with the lateral nasal artery. In two patients, the flap was passed through the subcutaneous tunnel. Venous congestion was observed in these two patients. Because of this risk, we preferred to make an incision starting from the nasion whenever required. A Penrose drain was placed underneath the flap before the adaptation of the flap to the defect. Postoperative antibiotics were administered for 5 days, and the sutures were removed 7 days after the operation.

\section{RESULTS}

The flaps ranged in size from $2.5 \times 2.5 \mathrm{~cm}$ to $4 \times 5 \mathrm{~cm}$. The widest flap in this series was $5 \mathrm{~cm}$, and we were able to close the donor sites primarily in all patients. Fifteen of the flaps completely survived, and temporary venous congestion was observed in the early postoperative period in three patients. Two of these cases resolved spontaneously, and in one patient in whom the flap was passed through the subcutaneous tunnel, distal flap necrosis was observed. The necrotic tissue was debrided, and skin was grafted subsequently. All the patients had a bulky appearance, but they not desire to undergo a second operation. The dissection of the flap took approximately 20 minutes, and the total operation lasted for 1 hour. The patients were hospitalized for 1-7 days (mean, 2 days) and the postoperative follow-up period was
1-28 months (mean, 17 months) (Table 1).

\section{Illustrative cases}

Case 1

A 75-year-old female patient was admitted to our clinic with a $4 \times 2.5-\mathrm{cm}$ lesion on her nasal dorsum (Fig. 2A). In the biopsy, the lesion was diagnosed as multifocal basal cell carcinoma (BCC). The tumor was excised with adequate margins. The $5 \times 3.5-\mathrm{cm}$ defect on the nasal dorsum was closed with a cranially-based nasolabial flap (Fig. 2B, C). The dimensions of the flap were $6 \times 4 \mathrm{~cm}$. The donor site of the flap was closed primarily following adaptation of the flap to the defect. No recurrence was observed. An acceptable scar was observed 4 months postoperatively (Fig. 2D).

\section{Case 2}

A 79-year-old man was admitted to our clinic with a longstanding lesion on his nasal dorsum and nasal tip (Fig. 3A). The lesion was excised with adequate margins following confirmation of the diagnosis (ulceronodular BCC). The resultant $3 \times 6-\mathrm{cm}$ defect included the nasal dorsum and the nasal tip region. The defect was closed with a cranially-based nasolabial flap that measured about $4 \times 7 \mathrm{~cm}$ (Fig. 3B, C). The donor site of the flap was closed primarily (Fig. 3D). The lesion did not recur, and a very acceptable result was observed 16 months postoperatively (Fig. $3 \mathrm{E})$. The resulting scars of both the donor and the recipient areas became almost imperceptible 14 months after the operation. The patient had natural features, and an excellent result was obtained with minimal bulk.

\section{DISCUSSION}

Congenital maldevelopment, cancer treatment, immune disease, and trauma can cause nasal deformities. The basic surgical principles of nasal reconstruction focus on restoring the preexisting form and function, without distortion of the adjacent structures [7]. The desired outcomes cannot generally be achieved by skin grafting alone. Local and distant free flaps are the possible flap alternatives for reconstructing defects of the nose. The disadvantages of reconstruction with free flaps are that it is time-consuming and complex, with a greater risk of morbidities. Local flaps have been described previously, such as the forehead flap, nasolabial flap, and various other local flaps [2,3,7-9].

The nasolabial flap is one of the most frequently used local flaps in the reconstruction of defects in the nose and perinasal region. Since its introduction by Blasius et al. in 1842, many authors have focused on the concept of the nasolabial flap $[6,10]$. 


\section{Fig. 2. Nasal defect reconstruction of case 1}

(A) A 75-year-old female patient with a lesion on her nasal dorsum. (B) A nasolabial flap was elevated and (C) the defect on the nasal dorsum was closed. (D, E, F) An acceptable scar was observed 4 months postoperatively.
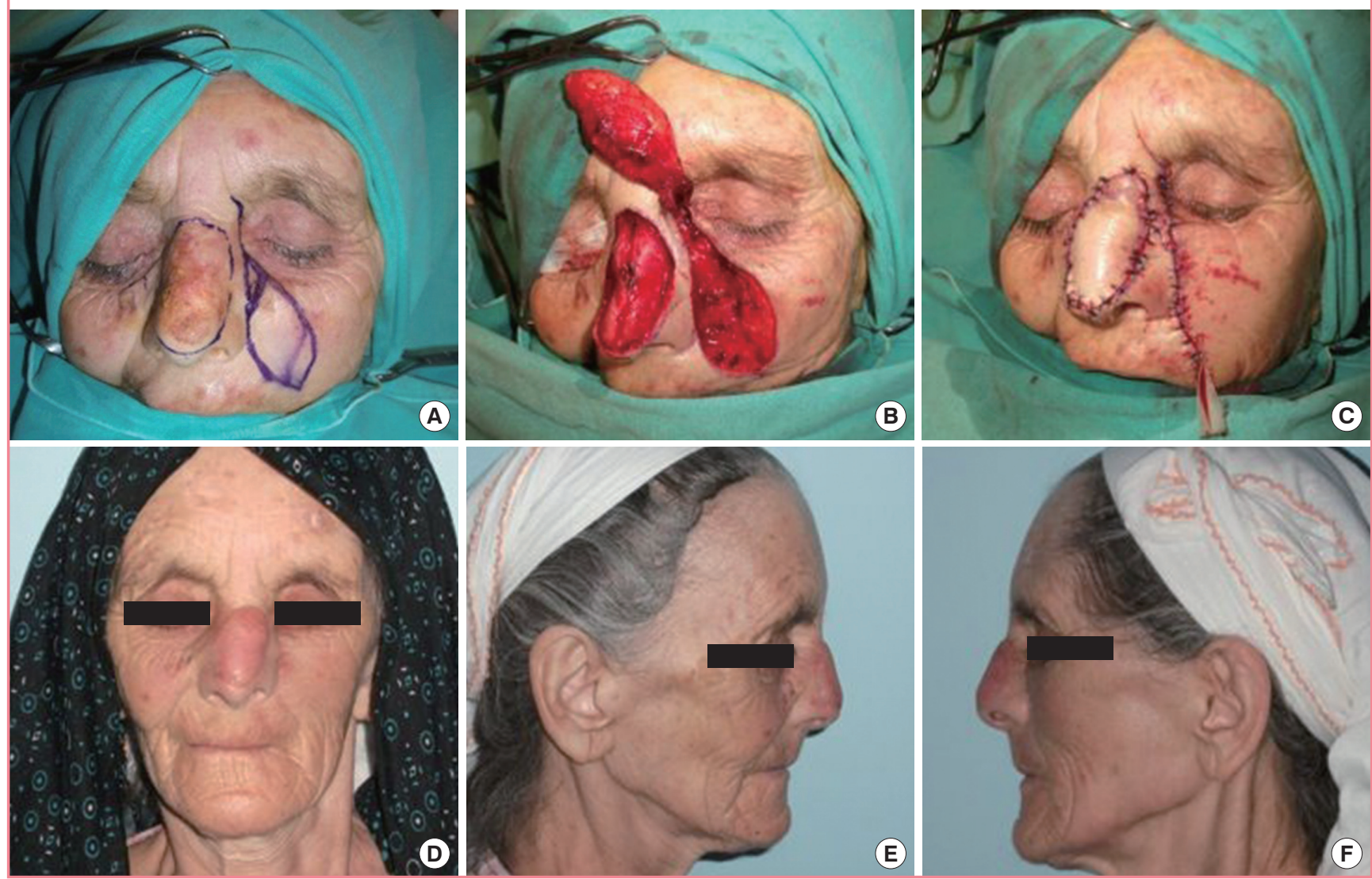

It is viewed as a safe flap for facial reconstruction depending on its specific patterns of vascularization. Many detailed cadaveric studies have confirmed the vascularity of this flap [11]. It is supplied by the facial artery and end branches of the angular artery in $70.5 \%$ of cases. The angular, lateral nasal, dorsal nasal, supratrochlear, and supraorbital arteries are connected to each other by numerous anastomoses [12]. Defining these territories will help in the proper design of the flap, enabling the surgeon to plan long axial flaps along the vascular axis between the medial canthus and the submental area $[12,13]$.

The technique of harvesting a nasolabial flap is quite practical, with an easy learning curve. It can be used in a wide variety of applications, ranging from reconstruction of the palate to reconstruction of the nasal wall. Donor site morbidity is minimal $[12,13]$.

The forehead flap is considered the gold standard for the reconstruction of nasal defects [14]. The forehead is considered to be an ideal donor site because of its perfect color and tissue compatibility, its high vascularity, and its ability to cover all the parts of the nose. However, the forehead is composed of skin, subcutaneous fat, frontal muscle, and a thin layer of areolar tis- sue that overlies the periosteum and bone. Therefore, all forehead flaps, regardless of their vascular pedicle, are thicker than the nasal skin when elevated. Traditionally, the forehead flap is transferred in 2 stages, incorporating later secondary revisions at intervals of 6-12 months. In the first stage, the partially thinned flap is inset into the recipient site. In the second stage, 3 weeks later, the pedicle is divided, its proximal aspect is re-elevated off the recipient site, and debulking is carried out. In smokers and in patients undergoing major nasal reconstruction, an additional operation is needed between transfer and division [15].

Since the proximal parts of the pedicle passed just above the periosteum, the prepared flap was thicker than the skin of the nose, which caused debulking to be necessary. However, none of the patients could be persuaded to undergo a second operation for cosmesis. The donor site of a forehead flap can be closed primarily, grafted, or left for secondary closure, and the forehead flap donor site scar is therefore often prominent. Conversely, the cranially-based nasolabial flap donor site scar is not evident, since the scar rests in the nasolabial sulcus.

The operation time, short hospital stay, compatibility of the tissue color, donor site scar location, patient comfort, secondary 


\section{Fig. 3. Nasal reconstruction of case 2}

(A) A 79-year-old male patient with a lesion on his nasal dorsum and nasal tip. (B) The lesion was excised with adequate margins, (C) a nasolabial flap was elevated, and (D) the defect on the nasal dorsum was closed. $(E, F, G)$ An acceptable scar was observed 14 months postoperatively.
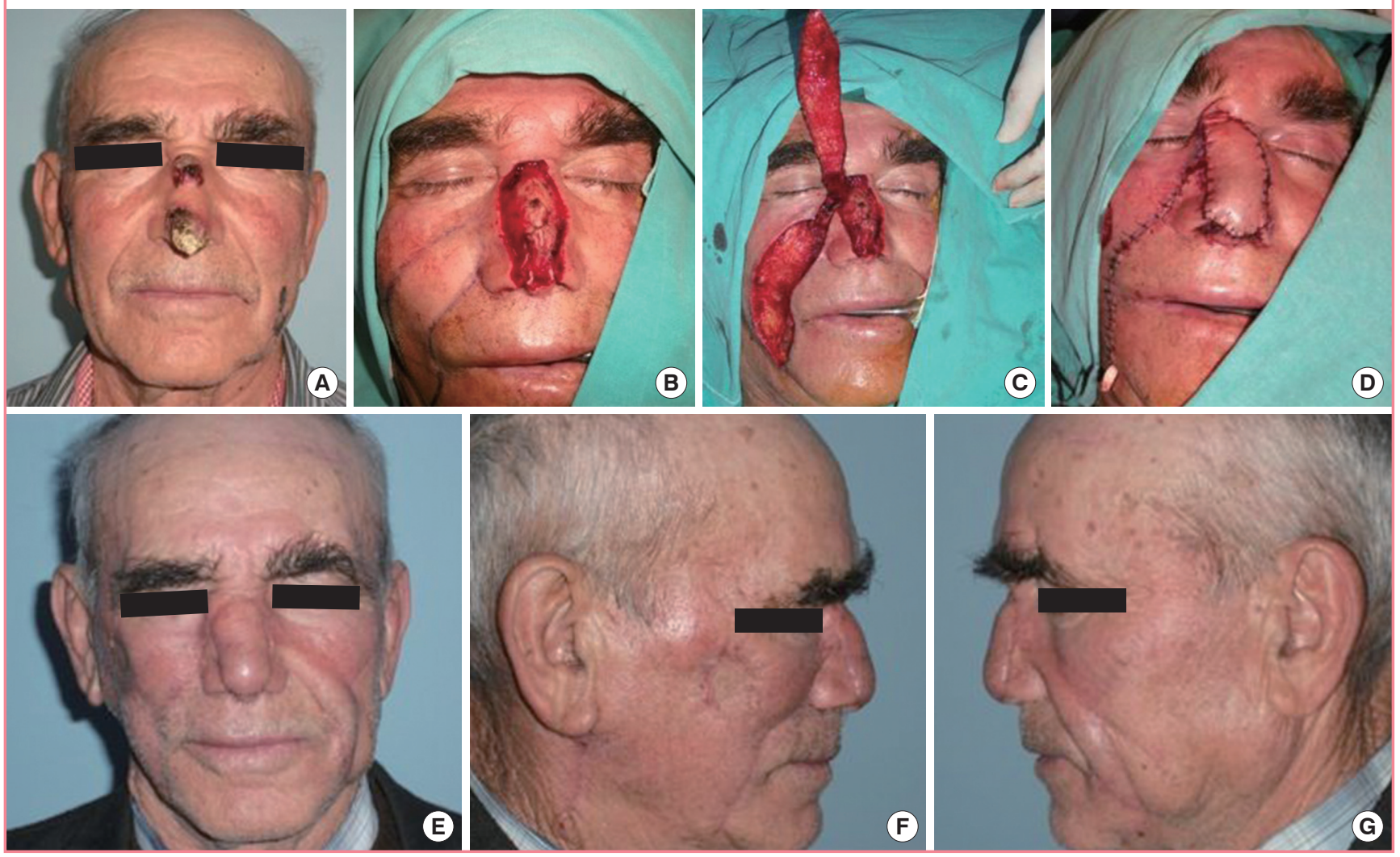

procedures, and cost-effectiveness are reasons to prefer this technique over free flap techniques. This method provided patients with an alternative to what would have otherwise been the necessity of a free flap.

Santos and Pappas [16] first introduced the contralateral nasolabial flap for nostril reconstruction in 1976. The donor site of this flap is quite lax, so the donor site scar is aesthetically acceptable. The dissection of the flap is quite simple, and can easily be performed in 15 minutes. When a flap on one side cannot be used for any reason, such as radiotherapy, the contralateral flap can be safely utilized. A rare contraindication is prior radiotherapy on both sides. We have previously reported the detailed dissection of this flap elsewhere. Its pedicle is quite reliable, with minimal variations. In that series, we presented the largest series yet published of cranially-based nasolabial flaps for the reconstruction of facial defects [6]. To the best of our knowledge, in this report, we present the largest series published thus far of cranially-based nasolabial flaps used for nasal reconstruction. Unlike the techniques described in other series, our technique would allow the flap to cover all aspects of the nose if its pedicle is stretched more cranially. As a result, the cranially-based nasolabial flap is a safe and reliable flap that can be used for the re- construction of nasal defects. It possesses all the advantages of the forehead flap and the traditional nasolabial flap. We propose that the cranially-based nasolabial flap is an important alternative that should be considered in patients with wide nasal defects.

\section{NOTES}

\section{Conflict of interest}

No potential conflict of interest relevant to this article was reported.

\section{Patient consent}

The patients provided written informed consent for the publication and the use of their images.

\section{REFERENCES}

1. Menick FJ. Reply: practical details of nasal reconstruction. Plast Reconstr Surg 2014;133:71e-72e.

2. Chu EA, Byrne PJ. Local flaps I: bilobed, rhombic, and cervicofacial. Facial Plast Surg Clin North Am 2009;17:349-60. 
3. Kwon KH, Lee DG, Koo SH, et al. Usefulness of V-Y advancement flap for defects after skin tumor excision. Arch Plast Surg 2012;39:619-25.

4. Gillies HD, Millard DR. The principles and art of plastic surgery. Boston: Little, Brown; 1957.

5. Dagregorio G, Baraer F, Darsonval V. Seven reconstructions of the orbital and periorbital region with a contralateral orbitonasolabial flap. Br J Plast Surg 2005;58:940-3.

6. Kerem H, Bali U, Sonmez E, et al. The cranially based contralateral nasolabial flap for reconstruction of paranasal and periorbital surgical defects. J Plast Reconstr Aesthet Surg 2014;67:655-61.

7. Poirson AB, Wandell BA. Task-dependent color discrimination. J Opt Soc Am A 1990;7:776-82.

8. Menick FJ. Nasal reconstruction with a forehead flap. Clin Plast Surg 2009;36:443-59.

9. Cameron RR, Latham WD, Dowling JA. Reconstructions of the nose and upper lip with nasolabial flaps. Plast Reconstr Surg 1973;52:145-50.
10. Silistreli OK, Demirdover C, Ayhan M, et al. Prefabricated nasolabial flap for reconstruction of full-thickness distal nasal defects. Dermatol Surg 2005;31:546-52.

11. Ng ZY, Fogg QA, Shoaib T. Where to find facial artery perforators: a reference point. J Plast Reconstr Aesthet Surg 2010;63:2046-51.

12. Ponte P, Goulao J, de Almeida JR. Contralateral nasolabial flap for a large nasal defect. Dermatol Surg 2009;35:675-8.

13. Whetzel TP, Mathes SJ. Arterial anatomy of the face: an analysis of vascular territories and perforating cutaneous vessels. Plast Reconstr Surg 1992;89:591-603.

14. Weng R, Li Q, Gu B, et al. Extended forehead skin expansion and single-stage nasal subunit plasty for nasal reconstruction. Plast Reconstr Surg 2010;125:1119-28.

15. Menick FJ. A 10-year experience in nasal reconstruction with the three-stage forehead flap. Plast Reconstr Surg 2002; 109:1839-55.

16. Santos OA, Pappas JC. Repair of nostril defect with a contralateral nasolabial flap. Plast Reconstr Surg 1976;57:704-6. 